\title{
Research Organisations in British Shipbuilding and Large Marine Engine Building Manufacture: 1960- 1977 (Part III)
}

\section{Hugh Murphy}

Cet article fait suite aux parties I et II, publiées dans les deux numéros précédents de cette revue. Il traite de la période 1960 à 1977, lorsque la grande majorité des entreprises britanniques de construction navale et de fabrication de gros moteurs marins ont été nationalisées par la British Shipbuilders Corporation en juillet 1977. L'auteur examine la publication de trois rapports historiques parrainés par le gouvernement sur la construction navale et la fabrication de moteurs marins en Grande-Bretagne, soit DSIR en 1960, SIC en 1965-1966 et Booz, Allen et Hamilton en 1973. Il examine également un rapport de 1962 sur la productivité de l'industrie de la construction navale et il termine en évaluant les répercussions de la BSRA, de Pametrada, de Doxford, du YARD et de la Division des navires du NPL sur la construction navale et la fabrication de moteurs marins en Grande-Bretagne jusqu'en 1977.

\section{The Department of Scientific and Industrial Research Report 1960}

Before the DSIR report's publication, ${ }^{1}$ nearly two years in gestation, the industry's representatives had the opportunity to see the report in its draft form, and this, somewhat predictably, provoked howls of protest by shipbuilders. So much so, that before the report's release, the industry's representatives had substantially

\footnotetext{
1 Department of Scientific and Industrial Research, Research and Development Requirements of the Shipbuilding Industries (London: HMSO, 1960), hereafter DSIR report.
}

The Northern Mariner / Le marin du nord, XXX, No. 3 (Fall 2020), 213-240 
purged many, but not all critical references in the initial report to management, productivity and labour relations. ${ }^{2}$

Subsequently, the curtailed DSIR report published on 15 December 1960 drew unwelcome attention to the many gaps in the British shipbuilding industry's R \& $\mathrm{D}$ efforts. The report's five conclusions were:

1. the world shipbuilding industry faced a major and probably prolonged recession,

2. there was no indication that the UK shipbuilding industry had on balance any marked technical or economic advantage over its major foreign competitors apart from its large home market,

3. the total effort at present devoted to research and development in the field of shipbuilding and marine propulsion is insufficient in relation to the serious problems now facing the industry,

4. that, in particular, almost no organized research has hitherto been applied to the industry's production and management problems with the object of increasing the productivity of labour and capital and reducing costs, and,

5. while adequate effort is probably being devoted to problems of hull resistance and propeller design, the development of propulsion installations is handicapped by the organisational structures of the industries producing propulsion units and auxiliaries and, in consequence, by the insufficient use of research facilities. $^{3}$

Despite the shipbuilding industry's attempts to excise parts of the report, its overall conclusions, points 2-5, were nonetheless damning. Point 4 brought into sharp focus Sir Maurice Denny's initial insistence in 1944, subsequently dropped in 1945 , on research into production methods, yard layouts etc. In a contemporaneous statement, the Shipbuilding Conference rejected DSIR criticism of PAMETRADA, but welcomed its offer of collaboration with the industry through the Ministry of Transport (then responsible for the mercantile side of the industry) to examine the research and development needs of the industry as a whole and to review arrangements for the promulgation of research. ${ }^{4}$

According to the DSIR report, up to September 1960, 5.8mshp of turbines to

2 Extracts of the original draft report were published by The Times (London) national newspaper on 8 October 1960 . Its report of 16 December 1960 on the published version noted that it had been purged of some admitted inaccuracies and questionable generalizations, but also of a great deal of serious and valid criticism of the industry in the original. Perusal of the draft report and the finished version confirms this.

3 DSIR report, 17.

4 Shipbuilding Conference Press Release Statement, 15 December 1960, National Maritime Museum, Greenwich, London Shipbuilders and Repairers National Association Papers, (NMM, SRNA). 
PAMETRADA ${ }^{5}$ basis designs had been completed. ${ }^{6}$ Taking the cost of employing a fully qualified scientist or engineer on $\mathrm{R} \& \mathrm{D}$ associated with shipbuilding and marine engineering at $£ 6,000 \mathrm{pa}$, estimated expenditure on shipbuilding $\mathrm{R} \& \mathrm{D}$ in 1958 (excluding BSRA, ${ }^{7}$ PAMETRADA and NPL) was approximately $£ 282,000$ and in marine engineering approximately $£ 1.2 \mathrm{~m}$, or a total of about $£ 1.5 \mathrm{~m}$ for the combined industries (excluding ship repair), around 1 percent of net output. This compared with 2.6 percent for manufacturing industry as a whole (excluding aircraft), and 1.8 for non-electrical engineering industry as a whole. ${ }^{8}$

In 1958, taking industry and government together, total expenditure on research was in the order of $£ 2.5 \mathrm{~m}$, around 1.7 percent of net output, the bulk of which was in marine engineering research. Taking the latter plus PAMETRADA expenditure and half of BSRA expenditure this amounted to $£ 1.9 \mathrm{~m}$ or about 4.4 percent of net output. ${ }^{9}$ In the larger power ranges $(5,000 \mathrm{bhp}$ plus) apart from Doxford, all British slow speed marine diesel engine building firms built under Doxford, Burmeister \& Wain (Copenhagen), or Sulzer (Winterthur, Switzerland) licences, with the exception of North Eastern Marine who also built to Swedish Gotaverken design and Fairfield who retained a Dutch Stork Werkspoor licence.

Indeed, between 1950 and 1959, the proportion of large main marine diesel engines built under licence to foreign designs increased from 25 to 46 percent, with all eleven British Doxford licencees also manufacturing foreign designed engines. The likelihood was that the better capitalised foreign manufacturers were now looking to intensify production of marine main diesel engines in power ranges up to and exceeding 20,000bhp. A fact acknowledged in March 1960, by the Science minister, Lord Hailsham, who expressed disappointment that there was no British main diesel engine of more than 11,000bhp, "while there are Continental designers who are developing engines of 20,000 bhp." 10

Doxford's output of direct drive main marine diesel engines in terms of cumulative brake horsepower produced was greater than either Sulzer and Burmeister \& Wain during the 1950s but its decline against these two firms was much more marked from 1962 onwards when both overtook Doxford in this category. ${ }^{11}$ What was not in doubt was that the demand for main engines would continue to vary directly with the demand on the shipbuilding industry. Licensees would also concentrate on what was popular with ship owners rather than sticking religiously to Doxford production.

The DSIR report noted that the industry, unsurprisingly given the situation, was

\footnotetext{
5 Parsons Marine Turbine Research and Development Association, Wm Doxford \& Sons, Sunderland.

6 DSIR report, 14 , note 1.

7 British Shipbuilding Research Association.

8 Industrial Research and Development Expenditure (London: HMSO, 1959), and DSIR report, para. 25.

9 DSIR report, paras 25-26.

10 Hailsham quoted in The Motor Ship April 1960.

11 The Motor Ship various years.
} 
currently reviewing the functions of BSRA and PAMETRADA, and that possibly new formal arrangements for coordinating research would ensue but recommended that this should include adequate participation by British ship owners. ${ }^{12}$

A shipbuilder, James Lenaghan, of the Fairfield Shipbuilding and Engineering Company at Govan voiced that the DSIR report was "largely an indictment and the industry must take note of it." ringing endorsement of the industries and their respective research institutions. Indeed, an impartial observer might have questioned their existence and relevance to date. A point not lost on the industry, which initiated its own report, in part due to DSIR criticism that practically no organized research had hitherto been applied to shipbuilding's production and management problems with the desired object of increasing the productivity of labour and capital, and in so doing, reducing costs.

Before the publication of the DSIR report and cogniscent of what criticisms of the industry it would contain, the Shipbuilding Conference, Shipbuilding Employers Federation, the National Association of Marine Engineers considered ways of improving productivity and developing research in the shipbuilding industry, and a decision was taken to form a permanent Production Research Section of BSRA. On the productivity side, this led to a committee chaired by $\mathrm{Mr}$ John Patton, which is discussed below.

\section{Patton Report, 1962}

The industry, cognizant of government dissatisfaction and a deteriorating position relative to international competition, instituted its own committee under the chairmanship of Mr James Patton, which eventually reported in February 1962. Its initial remit was to "examine the problems related to productivity and research in the shipbuilding industry, to make recommendations for improvement in all possible aspects of shipbuilding production, and to examine other methods to improve the competitive position of the industry." 14 By this stage the industry was aware of the threat of international competition. As the report's preface stated, "the placing of British orders abroad is not conclusive proof of an inherent inability of British shipyards to meet the challenge of foreign competition, but it a reminder that the industry must continue to move with the times and move faster."

From its first meeting on 29 June 1960, the Patton Committee members were either shipbuilders or marine engineers who then visited large, medium and small shipyards in West Germany, Holland, Denmark and Sweden. ${ }^{15}$ A report was sent to

\footnotetext{
12 DSIR report, para, 48.

13 Discussion of DSIR report, circa, January 1961, NMM, SRNA R4 18/2. Lenaghan would become one of the members of the Patton committee on Productivity.

14 "Productivity and Research in Shipbuilding: Report of the Main Committee under the Chairmanship of Mr James Patton to the Joint Industry Committee," February 1962, 3, author's collection.

15 Patton report, 4. The members visited four large yards in West Germany, two large yards, one medium and six small yards in Holland, one large yard in Denmark and four large yards and one
} 
the Shipbuilding Conference for dissemination to the industry in February 1962. It found that a substantial section of the industry was competitive with West German yards in particular, and that a small number of yards in Holland and Scandinavia were considered to be superior. It was noted that flexibility and interchangeability of labour in continental yards kept down labour costs. Flexibility was defined as "the freedom of a worker to undertake any auxiliary work to progress his own job," and interchangeability as "freedom of management to assign workers to work outside their normal trade group." Moreover, equally contentious, was the "freedom of management to decide manning levels of individual machines and jobs to suit circumstances." All this had a "significant effect in reducing labour costs of a ship built in a foreign yard." 16

Given that there were some twenty-seven trade unions in British shipbuilding and marine engine building, who all operated on the "closed shop" principle of compulsory 100 percent trade union membership and associated demarcation of trades, this was in reality a non-starter, particularly with the main hull trades union, the Amalgamated Society of Boilermakers and the main marine engineering trade union, the Amalgamated Engineering Union. ${ }^{17}$ Moreover, it would require a united front from shipyard owners, a factor singularly lacking in the past.

The report also noted the strength of technical staffs in the shipyards visited and noted that one Scandinavian yard claimed to employ one hundred graduates. It was not uncommon in British yards, in stark contrast to Scandinavian and Japanese yards, to have only a handful of graduates (usually in naval architecture or mechanical engineering) employed. Indeed, the report later stressed that "the British shipbuilding industry has a long tradition of working with a minimum managerial and technical staff and requires to learn how to effectively integrate and use specialist functions in its management structure, so that real advantage commensurate with the increase in overhead costs is obtained." 18

Minimising overhead costs by a pared-down management structure was an article of faith in British shipbuilding, thus this suggestion would imply a complete reversal of past practice in what remained an inherently parsimonious industry. Nevertheless, detailed recommendations on improving the industry's productivity and the importance of production research were intended to point the way forward, but no organisation was set up to manage the implementation of its

medium yard in Sweden.

16 Patton report, preface.

17 For labour in British shipbuilding generally, see Hugh Murphy, "Labour in the British shipbuilding and ship repairing industries in the twentieth century," in Raquel Varela, Hugh Murphy and Marcel van der Linden, eds., Shipbuilding and Ship Repair Workers around the World. Case Studies 19502010 (Amsterdam and Chicago University Presses, 2017), 47-116. For the boilermakers, see, J.E. Mortimer, A History of the Boilermakers Society, 3 vols., (London: George Allen \& Unwin/Verso, 1973-1994), and Alastair Reid, The Tide of Democracy: Shipyard Workers and Social Relations in Britain, 1870-1950 (Manchester: Manchester University Press, 2010). As yet, there is no comprehensive history of the Amalgamated Engineering Union.

18 Patton report, 75. 
recommendations. Save working with the Production Research Section of BSRA from 1961, which had three main sections of research. ${ }^{19}$

PAMETRADA, increasingly concerned with manufacturing standards of its member firms and associate members, had appointed a Manufacturing Liaison Officer in 1957, and in 1960 took the long overdue decision to produce fully toleranced working drawings for a range of standard designs. A Design Development Board comprising industry technical representatives was set up under the chairmanship of Graham Strachan of John Brown Engineering, Clydebank, and a standardisation section was created in the Design Department. ${ }^{20}$ In the interim, negotiations with government had progressed and the industry could announce in November 1961 a re-organization of its research activities to combine the activities of the old BSRA and PAMETRADA under a new body, with the same acronym but omitting shipbuilding, The British Ship Research Association.

\section{The British Ship Research Association}

In changing the name but not the acronym, the new BSRA formed on 3 May 1962 emphasised research into ship operation integrated with research into shipbuilding and marine engineering. Neither government nor industry gave adequate reasons for this change. To do so in any detail would have called into question the entire rationale of research since 1944. The new BSRA would take over PAMETRADA research activities relating to marine turbines and gearing. Despite this however, the marine engine building industry had decided to establish a non-grant-aided organization controlled by the marine turbine builders to take over the design and development activities in the marine turbine field previously carried out by PAMETRADA. Confusingly, the new organization would continue to be known as Pametrada (in lower case) with thirteen member firms and would work in close association with the new BSRA at Wallsend. ${ }^{21}$ Those sections of the existing PAMETRADA concerned with design, manufacturing liaison, production of working drawings and attendance at trials would be transferred to the new Pametrada. Its most important function would be design development, standardisation and control of steam turbines. This was seen as an "absolute necessity" for the marine turbine industry. It was unlikely because of cost considerations that any member firm could do the work themselves, and a joint effort was likely to prove cheaper and more effective. ${ }^{22}$

As in the past, shipowners would cooperate with BSRA, particularly by making ships available for practical tests, with the shipping industry well represented

19 The Motor Ship January 1963, article on BSRA by its director of research Sir Victor Shepheard $\mathrm{KCB}$. The three main sections were 1. planning, production control, shipyard layout and training in production methods. 2. A range of steelwork items. 3. Outfitting of ships and related matters.

20 R. Darling, 40 Years of Progress: A History of the Wallsend Research Station, 1945-1985 (London: British Maritime Technology, 1985), 46-47.

21 Press release, NMM, SRNA R4 20/1.

22 Ibid 


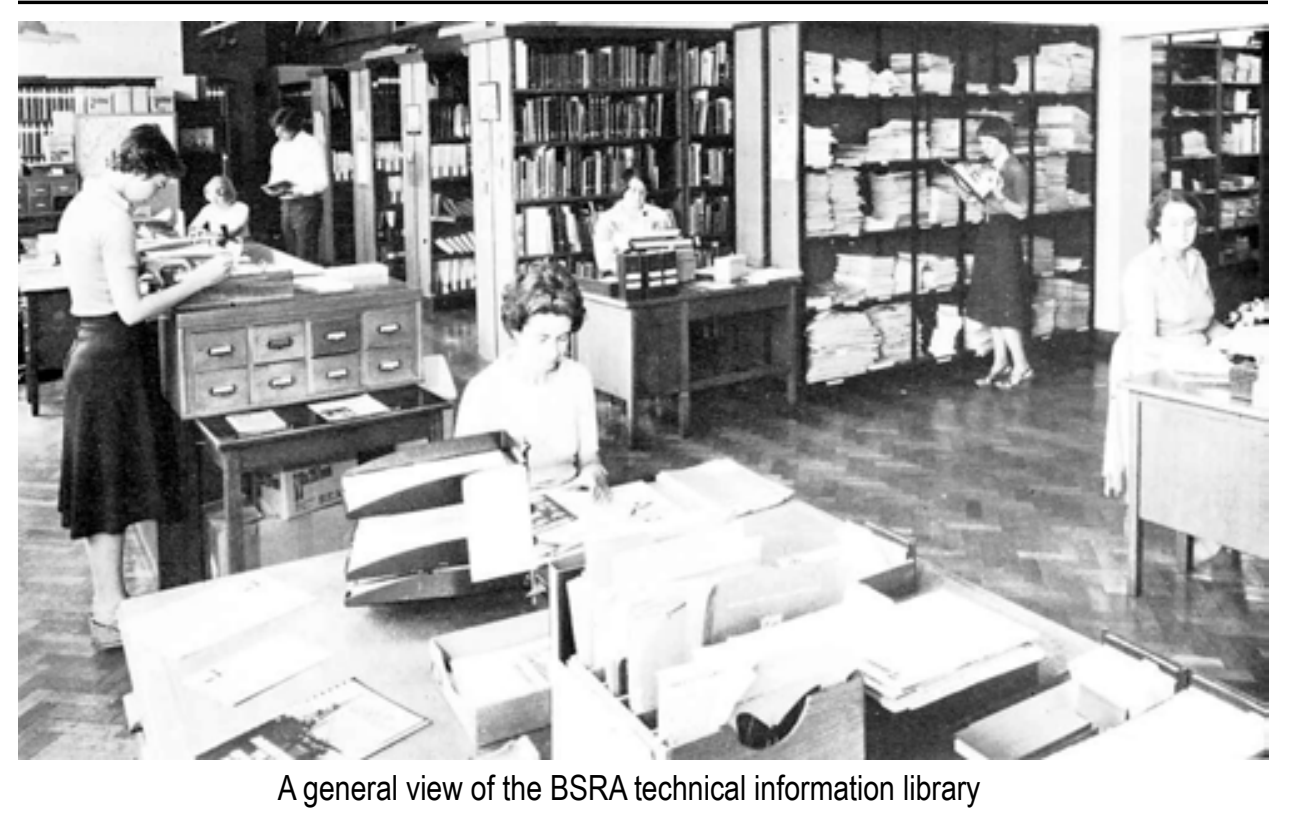

on the Research Council and on many technical committees and panels. British shipowners could apply for associate membership for $£ 50$ per annum. As to rationale, BSRA's director of research, Sir Victor Shepheard (1893-1989), stated that the main object of research was to "provide shipbuilders and marine engineers with data and information that will enable them to design and build better ships as economically as possible."23

BSRA Headquarters would be at Prince Consort House, Albert Embankment, London, concerned with central administration, naval architecture, production and intelligence activities, and it would also take over the old PAMETRADA's Wallsend Research Station where marine engineering research would be undertaken, and would continue to operate the structures testing establishment at Glengarnock, Ayrshire, in conjunction with Lloyd's Register. The new BSRA covered a wide range of research on both naval architecture and marine engineering fields. ${ }^{24}$ Its organizational structure was based on a research council containing three delegates of the Shipbuilding Conference, two from the National Association of Marine Engineers, one from the new Pametrada, three from the Chamber of Shipping, and representatives from government departments and trade unions..$^{25}$

In addition, the Production Division of BSRA had been operating for almost two years, covering planning, production control, shipyard layout, and training in production methods, steelwork and outfitting of ships. Another BSRA division

\footnotetext{
23 The Motor Ship January 1963.

24 It had committees on hydrodynamic research, ship structures, ship vibration, performance research, seakeeping, steam turbines, gas turbines, internal combustion engines, machinery installations, and materials.

25 Chamber of Shipping Research Bulletin, September 1963.
} 
was concerned with the application of atomic energy to merchant ship propulsion, but this was discontinued in 1964. All this required a great deal of expenditure to considerably increase the scope of research. It was anticipated that initial expenditure would be circa $£ 1 \mathrm{~m}$ per annum, a sum inadequate to meet research requirements.

Given the shipbuilding industry's difficult economic conditions, it was expected that government would give maximum financial assistance to the new BSRA, when legally constituted by the spring of 1962. In the interim discussions regarding financing continued with the DSIR. Subsequently, the latter undertook

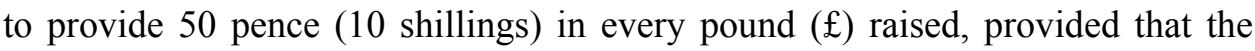
industry's financial contribution was at least $£ 600,000$ per annum - a threefold increase in past funding, and subject to a maximum DSIR grant of $£ 500,000$ per annum. In addition, DSIR offered as grant of $£ 1$ for every $£ 1$ contributed by shipowners, subject to a maximum of $£ 200,000 .{ }^{26}$ The greatly improved financial position allowed BSRA to recruit widely.

BSRA's director of research, Sir Victor Shepheard, retired and was replaced in April 1963 by a chemist and scientist, Mr Robert Hurst (1915-1996), formerly director of the Dounreay establishment of the Atomic Energy Authority. From the new BSRA's inception its research programs based in London and Wallsend had barely changed, but a disproportionate amount of resources was being used for marine engineering $\mathrm{R} \& \mathrm{D}$ in comparison to other divisions. Full-scale turbine testing ended in 1964 as did testing on gears and hydraulic transmission, and research on aerodynamics was sharply reduced. Simply put, the new BSRA was no longer willing to include research on prime movers within its own research program. ${ }^{27}$

By the 1964-65 financial year BSRA expenditure had risen to $£ 1,180,000$, and that of the Ship Division of the NPL to $£ 700,000$ (compared with $£ 280,000$ and $£ 230,000$ respectively in 1958-59) by which stage 144 professional staff were employed, and BSRA had been reorganized into four divisions: naval architecture research, marine engineering research, production research and a new project division. In the hydrodynamics field, continuing NPL Ship Division support was given. ${ }^{28}$ A shipowner division of BSRA was formed in 1965, initially combined with marine engineering. ${ }^{29}$

BSRA's support from DSIR ceased when that department was dissolved. The majority of its functions were taken over by a new Ministry of Technology, established by the new Labour Party government of Harold Wilson in October 1964. The Board of Trade proceeded to institute a wide-ranging inquiry into the British shipbuilding and marine engineering industries, which was eventually published a week before the 1966 General Election, which the Labour Party won

\footnotetext{
26 Report of the Shipbuilding Inquiry Committee 1965-1966 (London: HMSO, 1966), para. 469.

27 Darling, 40 Years of Progress, 59.

28 SIC report, 1965-66, paras 470-471.

29 Darling, 40 Years of Progress, 59.
} 
with an increased majority. ${ }^{30}$

\section{Pametrada}

In a submission to the SIC before it reported, the new Pametrada nominally had full responsibility for production and working drawing tolerance calculations, selection of materials, inspection of the finished product and liaison with manufacturers. ${ }^{31}$ Nevertheless, with no direct grant aid from government, Pametrada was ultimately reliant on industry backing in what was a difficult trading environment for the traditional steam turbine builders against the better capitalised land firms now making substantial inroads in the sector.

\section{Shipbuilding}

The effects of the continuing recession in freight rates from 1958-1961 were still being keenly felt by 1963 . As was noted in a leading article, "the short-term outlook for the yards is grim." 32 Indeed, by May 1963, the worsening situation had prompted the Conservative government to propose a $£ 30 \mathrm{~m}$ temporary one year only Shipbuilding Credit Scheme. Loans to build could be up to 80 percent of the cost of a ship and might be up to ten years duration, secured against first mortgages on the ships. The credit limit was soon raised to $£ 60 \mathrm{~m}$ because of its popularity, and by another $£ 15 \mathrm{~m}$ to accommodate a loan to the Cunard company to build a replacement for the passenger liner Queen Mary. By November the Credit Scheme was closed and in all, minus the projected replacement for the Queen Mary, sixtyseven vessels of 892,460 grt were constructed beginning in mid-1964. ${ }^{33}$ This gave the industry some breathing space against international competition, and a fillip to the marine engine building sector. It was perhaps the only scheme pertaining to the industry that was acceptable to shipowners and shipbuilders alike. Moreover, it was an example that governments in an election year could find money, which hitherto they were unwilling to give. The credit advanced was at cheaper rates than normally pertained. It may have had the outcome of merely accelerating orders already in the pipeline, or these orders may have been made in any event, but not necessarily in British shipyards.

By the time of the general election of October 1964 the number of workers engaged in new construction had fallen from 80,000 in 1959 to 47,600, and some world-famous shipyards had already gone to the wall. ${ }^{34}$ The incoming Labour

\footnotetext{
30 In the 1964 general election the Labour Party under Harold Wilson had a majority of one seat in Parliament over the two main opposition parties, the Conservatives and Liberals and other minor parties. In the 1966 general election that majority increased to forty-seven seats.

31 Memorandum on Pametrada undated, circa 1965, The National Archives, Kew, London (TNA), BT $186 / 20$.

32 The Times (London), 3 January 1963.

33 Lewis Johnman and Hugh Murphy, British Shipbuilding and the State since 1918: A political economy of decline (Liverpool: Liverpool University Press, 2002), 141.

34 Labour Statistics 1964, NMM, SRNA SEF 1.
} 
government faced a daunting task to revitalise an industry on the skids whose share of world output was at 8 percent, two-thirds less than it had been a decade earlier. Announced in November 1964, the government proposed through the Board of Trade (now responsible for merchant shipbuilding) to sponsor an independent inquiry into the shipbuilding industry to establish how best it could meet the challenges of international competition. ${ }^{35}$

\section{The Shipbuilding Inquiry Report 1965-1966}

Under the chairmanship of Anthony Reay Mackay Geddes (1912-1998), chairman of the Dunlop Rubber Company, the Shipbuilding Inquiry Committee (SIC), which reported to the President of the Board of Trade, did not contain any shipbuilders. The SIC report encompassed twenty-seven British shipbuilding firms producing ships of 5,000grt and over, all main engine builders, government departments and trade unions involved in shipbuilding, and shipping companies. In addition, SIC members visited yards and engine works in Denmark, Japan, Norway, Sweden, West Germany and the USA. The somewhat pious hope was that by restructuring the industry by mergers and rationalisation it would make it more internationally competitive.

The SIC report was, however, essentially an exercise in confidence building for an industry in danger of hurtling towards the rocks. The report's main recommendations were mergers of firms by specialisation on river centres, ${ }^{36}$ rationalisation of main marine engine building into four units, and the creation of a three-man Shipbuilding Industry Board (SIB) none of whom were shipbuilders, to stimulate reorganisation of the industry by facilitating mergers by grants and loans and covering transitional losses in so doing. ${ }^{37}$ The SIC Report found considerable evidence to support the contention that British shipyards were not internationally competitive, largely because the industry was too fragmented.

On BSRA, the SIC noted that negotiations with the Chamber of Shipping were successfully concluded in 1964 in order to meet the direct needs of shipowners. This called into question BSRA's name change, in that it took almost two years for this to happen and the enthusiasm or lack of it by shipowners. The SIC urged BSRA to increase its research efforts on ship's structural analysis, protective coatings, improved thermo-dynamic cycle efficiencies for steam turbines, mechanisation of crew functions, cargo handling, work study, noise and vibration

\footnotetext{
35 The Times (London), 11 November 1964.

36 SIC report. Each group would have not less than four shipyards and preferably five or six. The types of yards envisaged were, "S" yards, building sophisticated vessels (including warships) involving a large amount of fitting out work. "M" yards building multi-deck mixed cargo ships and "B" yards building bulk carriers and tankers.

37 Ibid., page 165. The SIB would allocate payments for the use of consultants to a ceiling of $£ 150,000$, various loans for capital purposes to a ceiling $£ 32.5 \mathrm{~m}$, a disturbance allowance to a ceiling of $£ 5 \mathrm{~m}$ and shipbuilding credits to a ceiling of $30 \mathrm{~m}$. The SIB, when constituted consisted of Sir William Swallow of Vauxhall Motors (Chair), Anthony Hepper of Thomas Tilling and Joe Gormley of the National Union of Mineworkers.
} 
and other machinery problems, and engine room layout. The SIC highlighted that the time was now opportune for a much more thorough analysis by the Chamber of Shipping "of areas of research that the chamber should initiate and support work at BSRA. ${ }^{38}$ Cognizant of the fact that it wished BSRA to expand its research, the SIC recommended that for three years from April 1967, a government contribution of $£ 200,000$ additional to the present funding should be made, providing that the shipbuilding industry made an annual contribution of $£ 600,000 .{ }^{39}$

On main engines the SIC noted three significant developments over the last decade: the decline of Doxford main engines, the decline of the steam turbine and the success of Continental designs. The committee also flagged up that geared medium speed diesel engine manufacturers had the potential to develop engines with higher power ranges and challenge the pre-eminence of the slow speed main diesel engine. They already had the backing of the National Research Development Corporation (NRDC) in this. ${ }^{40}$

In 1964, slow speed main diesel engines powered over 80 percent of ships of 5,000 gross tons and above launched in the world, and their share of the market was unlikely to fall before $1970 .{ }^{41}$ Nevertheless, current production was fragmented and uneconomic with the British shipbuilding industry remaining the main customer. Given this, the SIC recommended that main engine building should be concentrated into four production units capable of both main diesel engine and steam turbine manufacture or specialising in one type but separate from shipbuilding firms. Shipyard engine works should cease to manufacture main engines and the Doxford and Pametrada design teams should be integrated into one or other of these production units. ${ }^{42}$ To emphasise this, the SIC stated "until shipbuilders are prepared to exclude engine building from their engineering shops, we cannot rate very highly either their prospect of becoming competitive or their ability to take advantage of assistance we propose the Government should give them in the course of their reorganisation." ${ }^{43}$

The carrot in this for shipbuilding firms was funds for grouping made subject to SIB approval. Grouping would inevitably lead to a substantial form of both shipbuilding and main engine building rationalisation. During the early 1960s, cogniscent on the general rise in ship dimensions and tonnage, a number of spatially constrained shipyards with engine works had been liquidated, including Wm. Gray at West Hartlepool (Central Marine) in 1962, William Denny and Brothers at Dumbarton in 1963 and J. Samuel White at Cowes in 1965.

Rationalisation of main engine building was also unlikely in isolated locations

38 Ibid., para 477.

39 Ibid., para 487.

40 Ibid., para 187.

41 Ibid., para 191.

42 Ibid., chapter 11 and page 160.

43 Ibid., para 223. 
containing firms unlikely to group together. Good examples were Harland \& Wolff at Belfast and Vickers Ltd., at Barrow in Furness. Rationalisation had already taken place in the Richardsons Westgarth Group of main engine builders, when the group's HQ moved from Hartlepool to North Eastern Marine (NEM) Wallsend. The Group acquired Charles Parsons Turbinia Works in Newcastle-upon-Tyne in 1957, but Parsons left the marine steam turbine market in 1964. That year, NEM merged with the Sunderland-based main engine builders George Clark to form Clark-NEM. A year earlier, the Tyneside engine builders, Wallsend Slipway and Swan Hunter's Neptune Engine Works were combined, but Hawthorn Leslie (Engineers) Co. Ltd remained independent until nationalised in 1977, however, the Hawthorn Leslie shipyard was subsumed into the Swan Hunter Grouping on the Tyne in 1968. From the above it can readily be seen that the rationalisation of main marine engine building into four units proposed in the SIC report would more likely come about from industrial Darwinism rather than by design.

During the evidence gathering part of the SIC it received a deputation from the Ministry of Technology led by its permanent secretary, Sir Maurice Dean who gave oral evidence. The deputation stated that in comparison to other engineering industries the R \& D effort in shipbuilding was not large. Provisional figures for 1964-65 showed that total expenditure was less than $£ 5 m$. NPL Ship Division gross expenditure was $£ 640,000$ and BSRA $£ 932,000$. Total expenditure amounted to $£ 3,116,000$ of which over $£ 2 \mathrm{~m}$ was financed by government. The largest item of expenditure was marine engineering at $£ 2,457,000$ of which $£ 1,870,000$ was financed by government. On the basis of these figures the amount expended on shipbuilding research represented about $£ 6$ per head of total employment, and on marine engineering about $£ 55$ per head, or $£ 20$ per head average over the two industries. The latter figure was less than a third of expenditure per head in the electrical machinery industry and less than two thirds of that in the machine tools industry in the same year. ${ }^{44}$

The deputation also noted, unsurprisingly, that there was a growing division between shipowners and shipbuilders in respect of disclosure of results of research, but this was a greater problem with NPL work. Co-operation between NPL and BSRA was satisfactory. However, YARD ${ }^{45}$ was not an alternative to either of these organisations, being a consultancy for profit company. ${ }^{46}$

Of more pressing concern was the future of steam turbines and slow speed diesels. The weight and space of the latter put them at a disadvantage, although slower propeller revolutions gave greater propulsive efficiencies. However,

\footnotetext{
44 SIC extract from revised minutes of meeting held at Board of Trade, 8 December 1965, TNA, BT $186 / 5$.

45 Yarrow Admiralty Research Department and National Physical Laboratory, Teddington and Feltham, Middlesex.

46 SIC extract from revised minutes of meeting held at Board of Trade, 8 December 1965, TNA, BT $186 / 5$.
} 
European designers of these engines were of the view that this type of engine had reached its limit although their established dominance would continue for some time. The ministry saw potential in the medium speed diesel engine, which were smaller and through gearing could provide slower propeller revolutions at little or no extra cost. Moreover, the reduction in the use of steam turbines had the hallmarks of a trend, but that this could be partly reversed by orders for ships of $100,000 \mathrm{dwt}$ and over, but foresaw that in future these ships would be driven by diesel engines. ${ }^{47}$

A preliminary result of a recent study of medium speed engines commissioned by the ministry reported that at present ratings, medium speed engines just about broke even with slow speed. If the preliminary data in the study was right, then medium speed diesel engines would be subject to prototype grants. This did not augur well for Doxford, as the deputation did not deem it worthy of support as its engine's advantages were not sufficient to sway shipowners away from established foreign designs of slow speed diesels to any extent. ${ }^{48}$

In reply to the SIC questions on why there had been little government support for Doxford's J engine it was stated that "when Doxford's engines had been supreme, the firm had not carried on designing and had allowed its design team to run down. It therefore had no foundation on which to build." ${ }^{49}$ Commenting on a joint Doxford and BSRA proposal to uprate the J engine whose aim would entail a five-year development program, the ministry could not see an uprated Doxford engine at sea for a decade, and such a program would not enable Doxford to leapfrog competitors. Doxford had in fact turned down NRDC terms for a development contract as they desired half of the money to come from a government grant and the other half equally by themselves and BSRA. ${ }^{50}$

\section{Doxford in the 1960s}

Doxford's managing director (engineering) Robert Atkinson, had by March 1959 at a licensees meeting, began the process of more clearly defining relationships with licensees. ${ }^{51}$ The technical manager, D.B. Stables would be in charge of estimating, contracts, service and the technical office. Atkinson stressed that Stables was no longer basically concerned with the design of the engine nor indeed with the licencees' business at all. He had isolated all design matters to Percy Jackson and his new deputy, J.F. Butler, who Jackson had brought in from Harland \& Wolff. All R \& D and design would be Jackson's responsibility. Moreover, the test and liaison department would cease to exist, and its functions would be absorbed into

\footnotetext{
47 Ibid.

48 Ibid.

49 Ibid.

50 Ibid.

51 Drawings, Modifications, minutes of $17^{\text {th }}$ Meeting, 10-11 March 1959, Ballast Trust, Johnstone, Renfrewshire, Scotland. Uncatalogued Doxford Papers, Doxford Technical Organisation. Licensees' Administration.
} 
research. ${ }^{52}$ G.F. Oliver had been appointed as engineering director responsible to Atkinson and in sole charge of the company's technical affairs. His task was to ensure correct liaison between the technical manager on the marine engineering side and the director of R \& D on the design side. Atkinson again stressed that this was "new thinking for Doxford's," to ensure that in future "we speak with one technical voice." 53

This was evidently necessary as in the past all too often licensees had dealt with various people and got different answers to questions raised, with all that meant for design and technical matters, and performance of engines built under licence. Atkinson admitted that Doxford was largely responsible for this, but that licencees must also share responsibility as far too often, "things have been done on the basis of alleged telephone calls which subsequently can never be traced." ${ }^{54}$ Atkinson proposed to rectify this situation, and this was one of the main reasons for the appointment of G.F. Oliver, who now had the sole authorisation to commit the company by telephone or by letter to licensees as circumstances demanded. As to the past trend of licensees branching out on their own and modifying engines without agreement, Atkinson stated this was no longer acceptable practice, but in the case of important proposed modifications he would ask the technical heads of two or three of Doxford main licensees to come and discuss the matter. ${ }^{55}$

Atkinson was, in essence, trying to put past practice behind and look to the future. He acknowledged that there were so many modifications to Doxford main engines in existence, but that the way forward was as outlined. He intended to be firm in respect to design modifications to the new design range of engines and added a new aspect that his aim was interchangeability of parts and standardisation of the entire engine range. He posited that licensees would say "how can you have a standard engine with the drawings as issued by Doxford, which are guidance not production (close tolerance) drawings." Doxford were prepared for this as he had a revision team in the Drawing Office who for some months had been redrawing every one of the drawings for the 67 LBD4 main engine. ${ }^{56}$ To aid the process of modifications a Designs' Committee had been formed and Atkinson acknowledged the inadequacy of the past Doxford drawings, but when all drawings had been standardised no-one would have authority to modify engines in any respect without Doxford's written consent as a condition of Licence. Atkinson's overall aim was simply to have available for Licensees' use the best diesel engine at minimum price. $^{.7}$

Doxford were, in fact, open in their licence agreements in that licensees were

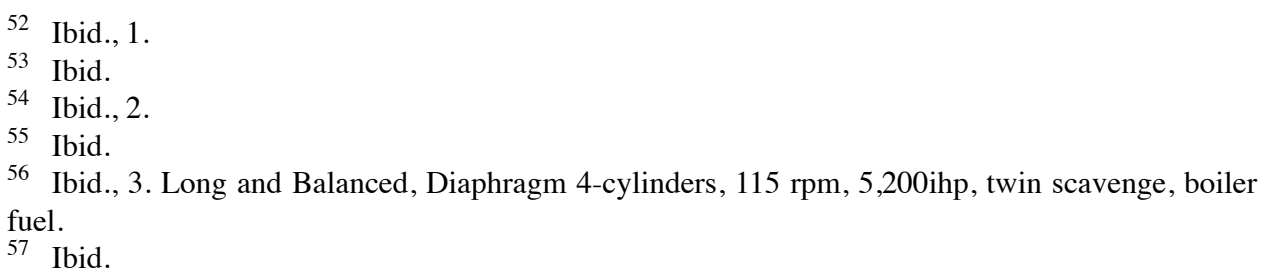


not precluded from manufacturing or overhauling other makes of main engines, which could be exported anywhere. The rival Sulzer licence precluded world-wide export and allowed export only to UK colonies and Canada. ${ }^{58}$

Clearly frustrated, as was his predecessor Arthur Storey with the direction of travel of Doxford under J. Ramsay Gebbie, Atkinson resigned in 1961 after three years in the job. In a much later interview, Atkinson, characteristically, made his feelings on Doxford at that time plain in a scathing quote: "there was a lethargic lot in charge who really behaved disgracefully. They lived the life of barons, the life of luxury, but did nothing intellectually or financially to push their country forward." ${ }^{59}$ Atkinson was replaced in 1 August 1961 by Thomas Westcott Davenport Abell (1910-1983) the son of a former Chief Ship Surveyor of Lloyd's Register, Sir Westcott Stile Abell, KBE.

In that year, merger talks were ongoing among Wear shipbuilders, specifically between Wm Doxford and the Sunderland Shipbuilding, Dry Docks \& Engineering (the shipbuilding yards of Sir James Laing and J.L Thompson, and the ship repairer, T.W. Greenwell Co., Ltd). After protracted negotiations a new holding company was formed in June 1961, titled the Doxford and Sunderland Shipbuilding and Engineering Co., Ltd., (DSSE) with each constituent company retaining individual boards and with J. Ramsay Gebbie as chairman of DSSE. Gebbie retired in June 1962 and was succeeded as chairman by Sir Henry Wilson (1904-1978).

Within the enlarged group, Doxford no longer could insist that the size of the engine built best suited their shipyard, which had an annual capacity of 75,000 dwt. Both Laing and more so Thompson could build larger vessels. R \& D work continued on a new more powerful main engine, the J-type. A Japanese consortium who visited Doxford just after the merger offered to build crankshafts and take out a licence for the new J-type engine, which promised a lower specific weight and was smaller in size for a similar output than continental engines. ${ }^{60}$ Gebbie, by this stage, predictably, vetoed the idea. Again, this was monumentally short sighted, not only would it have reduced costs, it would also have been lucrative in licence fees as Japan was easily the world's largest shipbuilder and would remain so for the rest of the century.

According to R.C. Thompson, deputy chairman of DSSE, beforehand, the DSSE Board had made the decision that it could not finance the development of a large bore main slow speed engine and approached first the DSIR for a development contract, who rejected the idea because the project was considered to be a development of an existing engine rather than an advanced prototype design.

\footnotetext{
58 Information to author from the late Dr J.F. Robb, Engineering Director Scott's Shipbuilding and Engineering Co., Ltd., Greenock.

59 Robert Atkinson interview in A. Slaven and H. Murphy, Crossing the Bar. An Oral History of the British Shipbuilding, Ship Repairing and Marine Engine Building Industries in the Age of Decline, 1956-1990 (Liverpool: Liverpool University Press, 2013), 218.

60 Patricia Richardson, William Doxford \& Sons Ltd. Shipbuilders and Engineers, Sunderland (Addington, Kent: Patricia Richardson, 2019), 233.
} 
Negotiations were begun with the NRDC who intimated that if the project failed, they would not expect repayment, but if successful, in addition to interest payments on the loan above market rates, they would expect royalty payments on all sales for a long period. During these negotiations a suggestion was made to integrate Doxford's research with that of BSRA in the lead role, which was not acceptable to DSSE on the financial terms proposed. DSSE then made the decision to break off negotiations for government financial assistance and postpone development of a large bore engine and were thus not in a position to offer main engines in excess of $21,000 \mathrm{bhp}$ in continuous service. ${ }^{61}$

The DSSE Board then made the decision to finance the development of a medium powered engine from its own resources and install one of the largest of these engines in an oil tanker built to its own account. Under Doxford's technical director, Percy Jackson, the DSSE board decided to build a full-size 760mm bore 9 -cylinder prototype J-type main engine to develop 20,000bhp and run at $115 \mathrm{rpm}$. The board commissioned the construction of an oil tanker from J.L. Thompson, in which it could be trialed. ${ }^{62}$ Clearly there was much riding on the success of the J-type. By 1964 Doxford, in terms of horsepower held 1.3 percent of the world market for slow speed main diesel engines. ${ }^{63}$ It had led the world in the interwar and post-war periods and for the rest of the 1950s in this category. According to Richardson, the J-type was tested for over 1,000 hours on the company's floating test bed at a massive cost of $£ 800,000$. $^{64}$

The J.L. Thompson 64,450 dwt tanker, North Sands began her sea trials with the prototype nine-cylinder J-type 76J9 main engine providing motive power in November 1965. The engine was found to be free of vibration, but slightly too powerful for the size of the tanker. Nevertheless, nineteen orders were taken valued at $£ 6 \mathrm{~m}$. Only one other $76 \mathrm{~J} 9$ was built for the much larger ore carrier Orenda Bridge of 135,308 dwt completed in March 1972. Nevertheless, the J-type, according to Hawthorn Leslie's Ben Crowdy was never attractive as it had the same power per cylinder as its single piston competitors, and despite iterations, fell behind the competition as its cost per horsepower was too high. Only one of Doxford's licencees, Hawthorn Leslie (Engineers) manufactured four J-types, before abandoning them for Sulzer main engines. ${ }^{65}$

By 1966, with eleven subsidiary companies, most of them loss-making, a decision was taken by Doxford in a year when an annual loss of $£ 3 \mathrm{~m}$ was posted,

61 R.C. Thompson, "Doxford Engine Research: Anomalies in Arrangements for Finance," The Motor Ship January 1967.

62 Ibid.

63 SIC report, 1965-1966, para 192.

64 Richardson, William Doxford and Sons, 234.

65 A. Storey and E.P. Crowdy, "The Final Years of Doxford," in Marine Engineering and the North East Coast. An historical symposium held at the Museum of Science and Engineering, Newcastle upon Tyne, 26 November 1988. Proceedings of the North East Coast Institution of Engineers and Shipbuilders 105, pt.2 (1989), 66. 
to absorb their trading activities into the holding company ${ }^{66}$ As to mergers in light of the SIC Report and SIB grouping funding, negotiations foundered on a merger with the other Wear shipbuilders, Austin \& Pickersgill and Bartram. By 1969 both these yards had merged on their own, leaving two shipbuilding groups on the Wear, as was the case on the Clyde. Neither DSSE nor Austin \& Pickersgill did well from SIB grants or loans, Doxford receiving $£ 13,000$ for consultancy fees, and A \& P nil. The four big winners were Harland \& Wolff $(£ 15,038,000)$, UCS $(£ 12,791,000)$, Swan Hunter $(£ 5,838,000)$, and Scott Lithgow $(£ 5,246,000)$, this out of a total $£ 42,925,000$ disbursed mainly in grants and loans by the SIB during its lifespan from 1967 to June $1971 .{ }^{67}$ Harland \& Wolff, Swan Hunter and Scott Lithgow all entered the VLCC market as a result. UCS imploded and was liquidated in 1972. Its successor, Govan Shipbuilders received $£ 35 \mathrm{~m}$ in government funding. As was noted by the Parliamentary Committee of Public Accounts in 1972, the bulk of funding from the state had been used "simply to meet company losses in order to avoid insolvency." ${ }^{68}$ Indeed, DSSE had lost $£ 2.8 \mathrm{~m}$ in 1970 and $£ 1.38 \mathrm{~m}$ in 1971 without any SIB support. ${ }^{69}$ It was in this climate where the shipbuilding industry was basically losing the plot that BSRA had to survive.

\section{The demise of Pametrada and its implications for steam and gas turbine manufacture in the UK}

Admiralty bias towards the land turbine firms was again confirmed in 1963 when a machinery contract for Royal Fleet Auxiliary fleet replenishment ships was placed without competitive tender with AEI well before the order for the ships was placed. This comprised single screw turbines of 20,000 to $25,000 \mathrm{shp}$ essentially of "merchant ship design." No opportunity was given to Pametrada to submit proposals. This put AEI in an even more favourable position as it gave it the opportunity to develop mercantile ships machinery, the cost of which was borne by the Admiralty who gave the turbine machinery as "free issue" to shipbuilders, (although delivery was more than a year behind schedule) and also kept AEI's design team in business. ${ }^{70}$

In October 1963 the Admiralty invited four selected firms, including Pametrada (the others were AEI, English Electric and Fairfield Westinghouse) to put forward competitive designs for a projected aircraft carrier (which was never built). Before

\footnotetext{
66 Richardson, William Doxford and Sons, 232.

67 SIB reports and accounts, 1967-1971. Broken down, Harland \& Wolff received £5.779m in grants, $£ 8 \mathrm{~m}$ in loans, $£ 1.6 \mathrm{~m}$ in interest relief grants. UCS, $£ 5.5 \mathrm{~m}$ in grants, $£ 3,520 \mathrm{~m}$ in loans, $£ 751,000$ in interest relief grants, $£ 21,000$ for consultancy fees and $£ 3 \mathrm{~m}$ in equity. Swan Hunter, $£ 5.816 \mathrm{~m}$ in grants, and $£ 22,000$ for consultants fees. Scott Lithgow, $£ 1.4 \mathrm{~m}$ in grants, $£ 3.8 \mathrm{~m}$ in loans, $£ 31,000$ in interest relief grants, and $£ 9,000$ for consultants fees.

68 Michael Davies, Belief in the Sea. State Encouragement of British Merchant Shipping and Shipbuilding (London: Lloyd's of London Press Ltd., 1992), 233.

69 Booz-Allen and Hamilton International BV, British Shipbuilding 1972. A Report to the Department of Trade and Industry (London: HMSO, 1973), 176.

70 Memorandum from Pametrada to SIC, 16 July 1965, TNA, BT 186/20.
} 
tendering, the Pametrada design was examined and considered satisfactory by the Admiralty and subsequent tenders invited. However, the order for design and machinery went to English Electric. No adequate reason was given as to why Pametrada failed to win the contract. As was noted in a submission to the SIC in July 1965, "it is difficult to resist the conclusion that the Admiralty had no intention of ever placing the order with Pametrada and merely went through the motions." 71

Again, the placing of work outside of the industry, as was the case with the fleet replenishment ships was to the detriment of the shipbuilding and marine turbine industry. Pametrada's submission to the SIC concluded, and in this author's view the evidence is overwhelming, that "in spite of the Admiralty's original stated intention of supporting Pametrada they have in actual fact indicated a persistent bias towards the Land Turbine Firms."72

At July 1965, over $7 \mathrm{msh}$ of turbines had been produced to Pametrada designs and every notable turbine driven merchant ship built in Britain had Pametrada geared turbines. ${ }^{73}$ In light of the recommendations of the SIC Report, with shipbuilders and marine engine builders likely to rationalise their activities or liquidate, the future was not bright. Discussions on the future of Pametrada intensified and by September 1966 the immediate decision facing it was whether or not it should stay in business. The crucial question to be decided was whether the shipbuilders desired to keep turbine design facilities under their control.

For the Shipbuilding Conference, its president, Michael Scott, stated that the conference had already turned down Pametrada's request for financial support, and that he could not go back to the conference executive board with the same request. From April 1967 there was likely only to be five member firms left and, in what amounted to a fait accompli, these firms intended to give notice of resignation to take effect at the end of the accounting year, 31 March $1967 .{ }^{74}$ Accordingly, so it proved and Pametrada was liquidated in the autumn of 1967.

Liquidation was confirmation that the land turbine sector who had engaged in marine turbine manufacture, steam and gas, had finally won out, and that British shipowners increasingly ordering abroad had substantially threatened its future prospects. The merger of British Thompson Houston and Metropolitan Vickers into Associated Electric Industries in 1959, and later AEI into the General Electric Company UK in 1967 and English Electric in 1968 into GEC brought the land impulse turbine firms into a single UK-based company, which had finally caught up with international competition.

The closure of Pametrada left AEI before its merger with GEC in a much stronger position both as manufacturer and licensor. The company had continued to design steam turbines for merchant ships during the period of Pametrada

\footnotetext{
71 Ibid.

72 Ibid.

73 Ibid.

74 Minutes of a meeting of Shipbuilding Conference and Pametrada, 20 September 1966, NMM, SRNA R4 20/6.
} 
operation, and had substantial experience in supplying turbines, steam and gas, and gearing to the Royal Navy. AEI had the necessary bedrock of substantial R \& $\mathrm{D}$ and materials technology knowhow, combined with licensing manufacture to its own designs. AEI's merger with GEC further enhanced its capability. Indeed, AEI had long coveted eventual supremacy in steam turbine manufacture. In June 1965 a deputation from AEI gave evidence to the SIC. The deputation was of the view that the shipbuilding industry and Pametrada should go out of the turbine business, leaving it to the land firms, they were satisfied that the industry could not support the fragmentation of production in works scattered up and down the country. The foreseeable future in their view would be covered wholly by the land firms or by a land firm and a residue of shipbuilding firms. ${ }^{75}$

The AEI view was given added credence by the rise in oil, bulk and ore carrier and container ship sizes. A very large crude carrier (VLCC) of 250,000 dwt required 30,000 shp on a single shaft, and by this stage the revolution of containerisation in the dry bulk sector had resulted in twin screw container ships with 20,000shp on each shaft. At the time, these high powers could best be met by steam turbines. The rise in average ship size meant that tonnage completed in British yards over the period from 1962 to 1971 increased by 21 percent but the number of ships completed fell by 40 percent, and aggregate main engine horsepower (diesel and steam turbines, including naval vessels) fell by 22 percent. ${ }^{76}$ However, when disagregated, slow speed main diesel engines completed had increased by 26 percent and steam turbines had decreased by 92 percent (excluding AEI output). ${ }^{77}$ This, however, left $\mathrm{AEI}$ and later GEC in a monopoly position, but with a decreasing UK market as only three shipbuilders could build VLCCs. ${ }^{78}$ Moreover, between 1966 and 1971 over 85 percent of UK tanker tonnage was built abroad. ${ }^{79}$ To add to GEC's woes, the major customer, the Royal Navy continued to decrease in size. On Pametrada's demise, BSRA closed its London office in November 1968 and moved to Wallsend. With Pametrada now defunct, its past came back to haunt those associated with it.

\section{Pametrada and the $Q E 2$ debacle}

For a substantial part of the twentieth century, the Cunard company had been the subsidy junkies of British shipping. Government had assisted the construction of the passenger liners Mauretania and Lusitania, both launched in 1906 at Swan Hunter \& Whigham Richardson at Wallsend and John Brown at Clydebank respectively, and in 1930 that of the Queen Mary, which was not completed until May 1936. ${ }^{80}$

\footnotetext{
75 Minutes of Ninth Meeting of SIC, 25 June 1965, TNA, BT 186/1.

76 Booz-Allen report, 191.

77 Ibid.

78 Swan Hunter, Tyneside, Harland and Wolff, Belfast and Scott Lithgow, Port Glasgow.

79 Dennis Thomas, "Shipbuilding-demand linkage and industrial decline," in Karel Williams, John Williams and Dennis Thomas, Why are the British bad at Manufacturing? (Henley on Thames: Routledge, Kegan and Paul, 1983), 194.

80 Cunard Agreement (Money) Act 1904, 4 Ed. VII, C.22. Cunard Insurance Agreement Act 1930,
} 
Cunard again approached the government for loans to enable the construction of a sister ship at Clydebank, Queen Elizabeth, which was not delivered until February 1940. Both ships served as troop carriers during the Second World War, and the loans, which had favourable interest rates, were repaid by 1946, well before their maturity date. ${ }^{81}$

Cunard again approached the British government in 1960 for a loan to aid the construction of a replacement passenger liner for the ageing Queen Mary, which resulted in the North Atlantic Shipping Act of 1961. However, Cunard changed its mind and it was not until 1963 that it again announced its intention to build a replacement liner and was granted a loan to do so of $£ 17.6 \mathrm{~m}$ under the temporary Shipbuilding Credit Scheme on terms less favourable than its previous application. ${ }^{82}$ Only on 30 December 1964 did Cunard sign a contract to build the ship.

The Queen Elizabeth II (QE2) was the last true transatlantic passenger liner built in a British shipyard, in this case at John Brown's shipyard in Clydebank. It was universally seen as a symbol of British shipbuilding and engineering excellence and as an emblem of national prestige. Completed in November 1968, she left for final fitting out at the Firth of Clyde Dry Dock at Greenock. ${ }^{83}$ On 17 December she exceeded her contract speed on trials on the measured mile off the Island of Arran. Subsequently she sailed to her home port of Southampton, but her Pametrada designed turbines subsequently failed on a trial run to the Canary Islands on 24 December, by which stage, her prospective owners, Cunard, had still not accepted the ship. She returned to Southampton on 2 January and by 5 January investigations were carried out into her turbine failure by personnel from John Brown Engineers. According to Douglas Ogilvie of Hawthorn Leslie (Engineering) and the last chairman of Pametrada, who accepted his former organisation was responsible, the fault could only have been found when the ship was at sea as the design had passed its laboratory tests. A dozen engineers had worked on the design, four of whom, including its chief designer, went to John Brown when Pametrada had been liquidated. ${ }^{84}$

Ogilvie's basic point about the fault only being found at sea was reinforced by the fact that the only UK test facility which could have housed the turbines before installation in the ship and tested them 20 percent above normal operating speed was BSRAs Wallsend Station test bed, but it had been out of use for five years. This prompted a daily newspaper, the Newcastle Journal to opine that it would be

$21 \& 22$ Geo. V, c.2, North Atlantic Shipping Act 1934, 24 Geo. V, c.10. North Atlantic Shipping Act 1961,9 \& 10 Eliz. 2. c53.

81 Davies, Belief in the Sea, 114-15.

82 Brian W. Hogwood, Government and Shipbuilding (Farnborough: Saxon House, 1979), 61.

83 For the history of the dock, see Lewis Johnman and Hugh Murphy, "No Light at the End of the Dock. The Long Rise and Short Life of the Firth of Clyde Dry Dock Company," International Journal of Maritime History 12:2 (1998), 91-123.

84 The Times (London), 7 February 1969. 
wise to reopen the Wallsend test bed as a national facility. ${ }^{85}$ A year later, it had been demolished. ${ }^{86}$

When the turbines were opened for inspection on 5 January 1969, it was discovered by John Brown Engineers that owing to "steam excitation" the rotor blades of one of the stages of the starboard high-pressure turbine had been stripped off. They had got caught up in other rotor blades and stripped those off in turn. Accordingly, after investigation it was found that the Pametrada design of the blades was at fault. Under operating conditions, the rotors were sheared away at the root. The rotors were airlifted to Clydebank on 6 January. An independent report by Sir Arnold Lindley, president of the Institution of Mechanical Engineers concurred with the John Brown Engineering findings, he stated: "the cause of blade failure in both rotors is resonant vibration in tangential (clamp pin) mode, caused by excitation from the steam issuing from the preceding steam nozzles. It is a phenomenon well known to steam turbine engineers not only in Britain but also in America and Europe, and in the case of marine turbines which operate under variable speed conditions, this excitation is particularly difficult to avoid." $\$ 87$

Modifications were subsequently made to the rotor blade design, the old blades were replaced, and the rotors were returned to the ship at Southampton on 21 March. After a trial voyage to West Africa, the turbines performed satisfactorily and $Q E 2$ made her maiden voyage from Southampton to New York on 2 May $1969 .{ }^{88}$ Bearing in mind that it was convenient to pin the blame on a defunct organisation, Pametrada did not have sufficient experience of vibration problems with impulse blading. Thus, the ghost of Pametrada had come back to haunt it: its reputation sullied in the eyes of the public. One great design failure dammed an organisation whose designs had powered 500 ships.

\section{Doxford in the 1970s}

Doxford held just 17 percent of the UK main marine engine market in $1970 .^{89}$ This despite the large marine engine building sector (slow speed diesel and turbine), being reduced from eighteen firms in 1966 to nine by 1972. Seven of the nonland turbine firms identified in the SIC Report no longer manufactured main marine engines..$^{90}$ The Doxford Group was vulnerable to a bid and succumbed to takeover by the conglomerate Court Line in July 1972. ${ }^{11}$ Accordingly, the name

\footnotetext{
85 Newcastle Journal, 2 February 1969.

86 Darling, 40 Years of Progress, 65.

87 Great Britain, House of Commons Debates, 3 March 1969, vol., 779, cc. 41-5 W, at 42 W.

88 New York Times, 8 May 1969. This took four days, 16 hours and 35 minutes.

89 Booz-Allen report, 190.

90 These were Cammell Laird, Alexander Stephen, John L. Thornycroft, Vickers Ltd, Wallsend Slipway, J. Samuel White, and Yarrow. Fairfield Rowan closed in March 1966, and AEI and English Electric were independent until they merged within GEC.

91 In addition to owning an airline and associated package holiday business and hotels, Court Line already owned a small covered shipyard at Appledore, Devon and North East Coast Shiprepairers, a substantial group of ship repairing firms.
} 
of the holding company was changed to Sunderland Shipbuilders Ltd., (SSL). Government funding of $£ 9$ m was sought for SSL to build a covered construction hall (its length later proved inadequate) at the Pallion yard. A grant of $£ 9 \mathrm{~m}$ was made conditional on Court Line finding $£ 3 \mathrm{~m}$ from its own resources. It did not have sufficient funds; accordingly, the offer of a grant was withdrawn, and work on the construction hall began in 1974 with the aid of a $£ 4 m$ overdraft facility from the National Westminster Bank. ${ }^{92}$ However, Court Line imploded under a mountain of debt in August 1974, and its shipbuilding, engineering and ship repair activities were rescued by the minority Labour government apparently at a cost of $£ 16 \mathrm{~m},{ }^{93}$ whose manifesto policy was to nationalise what was left of the British shipbuilding industry. ${ }^{94}$ SSL was now in effect nationalised. The government already wholly owned from September 1972 Govan Shipbuilders on the Upper Clyde. ${ }^{95}$ And, from 1970, a 50 percent shareholding in Cammell Laird at Birkenhead ${ }^{96}$ and through the Northern Ireland Ministry of Commerce a near 48 percent shareholding at a cost of $£ 4 \mathrm{~m}$ in Harland and Wolff at Belfast. ${ }^{97}$

\section{Seahorse}

With its shipyard under real competitive pressure and its main marine engine share declining, Doxford had earlier sought, in partnership with Hawthorn Leslie (Engineers), to develop a medium speed main marine engine, which would also be suitable for the land-based power generation market. ${ }^{98}$ Doxford's largest main engine to this point was the nine-cylinder $76 \mathrm{~J} 9 \mathrm{C}$ with a maximum brake horsepower of 27,000 bhp at $119 \mathrm{rpm}$. The cost of developing a competitive medium speed marine engine was beyond Doxford's resources, hence the joint venture with Hawthorn Leslie. The Doxford Seahorse was in effect a development of the opposed piston main engine, but was conceived as a $560 \mathrm{~mm}$ bore, four to seven cylinder medium speed main engine to drive larger ships with appropriate gearing (it could be geared down to produce $67 \mathrm{rpm}$, with attendant saving in fuel),

92 Court Line, Final Report (London: HMSO, 1978), paras 285-291.

93 This figure is taken from the interim report on Court Line published in 1975, and not repeated in the Final Report.

94 For the run-up and eventual rescue of SSL, see, Court Line, Interim and Final Reports of the Board of Trade Inspectors into the Affairs of Court Line Ltd. (London: HMSO, 1978).

95 Upper Clyde Shipbuilders was formed in September 1967 and was liquidated in June 1971, sparking the famous UCS Work-in. Its successor, Govan Shipbuilders began trading in September 1972.

96 In 1970 government through its Industrial Reorganisation Corporation took a 50 percent stake in Cammell Laird (Shipbuilders and Engineers) Ltd., from the Laird Group of Companies. Cammell Laird's losses from 1969 to 1971 amounted to over $£ 12 \mathrm{~m}$.

97 Harland \& Wolff, the largest employer in Belfast was always a special case. It received $£ 15 \mathrm{~m}$ from the SIB for capital expenditure projects, mainly to enter the VLCC market, and substantial sums including grants from the Northern Ireland Ministry of Commerce to stem losses.

98 A company, Doxford Hawthorn Leslie Research Services Ltd., was formed in June 1970 with an authorised capital of $£ 1,000$ in $£ 1$ shares fully paid up in equal shares by the parent companies. 
with the aim to develop 2,500bhp per cylinder at $300 \mathrm{rpm}$ and when twinned able to drive larger ships or for land power generation projects. Although three-quarters of new ocean going tonnage was powered by slow speed diesel main engines, it was evident that by this stage the direct drive main diesel engine would in time be seriously rivalled by manufacturers of medium speed diesel engines with reduction gearing during the 1970s. Three other British firms, Crossley, Mirrlees National, and Ruston \& Hornsby were active in developing medium speed engines. Of the large engine designers in 1966, only Doxford and Gotaverken were unable to offer a medium speed alternative to the slow speed engine. ${ }^{99}$

\section{Struggle}

Doxford struggled to win orders for their extant range of main engines and laid off two hundred men (20 percent of its workforce) in January 1974, with testing and modification of the Seahorse engine continuing. The collapse of Court Line that year and the continuing fall out in western economies consequent on the quadrupling of the price of crude oil by OPEC in 1973-74, combined with increasing inflation dogged the Seahorse project, as did minimal government support, even though the firm was nationalised. ${ }^{100}$ This situation was further exacerbated with the engine's potential super tanker market in the doldrums post OPEC with a massive amount of tanker tonnage laid up and cancelled, allied to the government's decision to back private medium speed manufacturers, rather than Doxford. The bulk of government funding in conjunction with the National Research Development Council had gone to the Rustin AO 12-cylinder medium speed engine geared to a single shaft, which twinned in service, proved disastrous. ${ }^{101}$ The AO engine failed in service as it was utterly unreliable; causing serious delays and loss of earnings for various shipping companies, including Reardon Smith, Hugh Hogarth, Lyle Shipping and Lambert brothers who all replaced AO engines in their ships in 1973-74. ${ }^{102}$ After consuming some $£ 5 \mathrm{~m}$ in joint funding no Seahorse medium speed engine ever graced a ship as none were ordered, and, under the nationalized British Shipbuilders Corporation new engine work ceased in 1980 and Doxford Engineers concentrated on repair

\footnotetext{
99 Marine Engineer and Naval Architect, April 1966, 144.

${ }^{100}$ For the effect of the OPEC price hikes on the tanker market, see Hugh Murphy and Stig Tenold, "The effects of the oil price shocks on shipbuilding in the 1970s," in Varela et al, Shipbuilding and Ship Repair Workers around the World, 665-674.

${ }^{101}$ Rustin and Hornsby of Lincoln were taken over by English Electric in 1966 and became part of GEC in 1969.

102 Seafarer, Reardon Smith's seafarer's newsletter, issue 26, March 2003, 10. The AO engines on the Welsh City were replaced by IHI in Japan with French SEMT Pielstick medium speed engines built under licence. Hogarth, Lyle and Lambert's ships were all managed by Scottish Ship Management Ltd., Glasgow, and the AO engines were all replaced in 1973-4. Both Hugh Hogarth and Lyle Shipping replaced AO engines on seven vessels in drydock in Amsterdam as did Lambert with four ships. The replacement Stork Werkspoor medium speed engines developed engine bedplate fractures and propeller hubs had to be replaced. See, John Orbell, From Cape to Cape: The History of Lyle Shipping (Edinburgh: Paul Harris, 1978), 154-155.
} 
and maintenance of extant engines, which turned out to be profitable. Doxford's research team was maintained by British Shipbuilders' new chairman, Robert Atkinson, (who had left Doxford in 1961) and in 1983 the engine works were rebuilt but were closed in June 1984 by Atkinson's successor as chairman, Graham Day.

\section{BSRA and NPL to 1977}

From March 1968, the test bed, boiler house, research house and turbo-combustion building at the Wallsend Research Station were all put on a care and maintenance basis, and a number of external research contracts on diesels were either run down or terminated. ${ }^{103}$ By 1970 the government grant to BSRA, 66.66 percent conditional on an annual income of $£ 1.2 \mathrm{~m}$, was $£ 915,058$ at the year-end 31 March. By the 1971-72 financial year the Shipbuilding Conference had reduced its contribution to BSRA to $£ 500,000$ per annum and government had reduced its grant to 60 percent. ${ }^{104}$ By this stage, the Booz-Allen report had noted that "all indications are that UK research effort is adequately financed and that the quality of research is high...however, research and development in the UK shipbuilding industry has not been effectively co-ordinated...BSRA by its composition and method of support is not currently considered to be an effective vehicle for co-ordinating shipbuilding research effort." 105 The report also pointed to a lack of specific practical objectives, lack of cost benefit analyses, research went on too long without adequate return, and value for money was not obtained. ${ }^{106}$ This was pretty damning and to a large extent presaged a change in government policy towards research associations.

A more successful instance of BSRA R \& D was the application of computers in the design process to shipbuilding. A Computer Division was formed in 1969. Under the generic title BRITSHIPS, programs were developed for stability analysis plus powering, manoeuvrability and seakeeping analysis, as were programs to create the optimum ship design for a particular trade based upon economic criteria. Numerical control for cutting ship's plates either under the older and more established Norwegian Autokon CAD/CAM system ${ }^{107}$ or a newer BRITSHIPS 2 CL program were taken up by British shipbuilding firms. ${ }^{108}$ BRITSHIPS gained BSRA a Queen's Award for Industry in April 1974. In that year, work on a computer aided Ships Structural Design System (SSDS) moved forward and had a budget of

\footnotetext{
103 Darling, 40 Years of Progress, 59.

104 Annual reports various years, NMM, SRNA.

105 Booz-Allen report, 54

106 Ibid.

107 CAD (computer aided design). CAM (computer aided manufacture). For Autokon and its application in shipyard lofting and steel plate fabrication, see, E. Mehlum and P.E. Sørenson, "Example of an Existing System in the Ship-Building Industry: The Autokon System," Proceedings of the Royal Society of London (1971), 219-233.

108 These systems were introduced into the Mould Loft and quickly replaced the traditional full-scale lofting process or the more recent tenth-scale lofting system.
} 
$£ 500,000 \mathrm{pa}$, but progress began to fall behind what had initially been budgeted for. Indeed, the amount of work needed to perfect the system had been seriously underestimated. ${ }^{109}$

In conjunction with SSDS, a long overdue change in BSRA funding occurred in April 1974, when the old DSIR type inspired proportional payments to research associations ceased and was replaced by seven Requirements Boards of the Department of Industry to place contracts in support of specific projects, thereby establishing customer contractor relationships. For BSRA, the appropriate board was the Ship and Marine Technology Requirements Board (SMTRB). Of five projects tendered for, BSRA was successful in four, and the SMTRB agreed to fund 50 percent of the costs of each project (including SSDS) for a number of years subject to satisfactory progress. This meant that BSRA would have to finance all of its other activities from its own resources. ${ }^{110}$

The changed circumstance meant that a criticism of BSRA that by its composition and method of support it was not an effective organisation because of the large number of areas of research to which it was committed, now had much less force, in that it now had to concentrate on fully-funded projects. Nevertheless, reliance on the SMTRB for new rather than extant funding, would be difficult. ${ }^{111}$ Furthermore, with many of its member firms in financial difficulties, the Shipbuilding Conference had reduced its funding to BSRA to $£ 400,000$ where it remained to 1976 before nationalisation of the shipbuilding industry. ${ }^{112}$

Up to nationalisation in July 1977, BSRA soldiered on at Wallsend but did not become a constituent part of the British Shipbuilders Corporation. Responsibility for the NPL passed from the Department of Trade and Industry to the Department of Industry in 1974 and in July 1976 the NPL Ship Division and Maritime Science Division were transferred to the National Maritime Institute Ltd., who took over responsibility for research into performance, handling and safety of ships and offshore structures. ${ }^{113}$ YARD remained separated from the nationalised Yarrow shipyard and continued its consulting role in premises in central Glasgow, and BSRA after most of the privatisation of British Shipbuilders Corporation had taken place, was subsumed into NMI Ltd. in 1985.

\section{Conclusions}

The British shipbuilding and associated marine engine building sector were

\footnotetext{
109 Darling, Forty Years of Progress, 82.

110 Ibid., 67. Darling missed out "Technology" in the board's title. The other successful tenders were for Advanced Technology Shipbuilding, Propeller Excited Vibration, and Standards.

111 Department of Industry Report on Research and Development, 1974-1976 (London: HMSO, 1977). Industry orientated R \& D grew by 19 percent between $1974-75$ and $1975-76$ from $£ 78.9 \mathrm{~m}$ to $£ 94 \mathrm{~m}$ but was estimated to rise by only 5 percent in $1976-77$ to $£ 98.7 \mathrm{~m}$. In this the SMTRB budget was raised by only $£ 54,000$. See also, New Scientist 19 May 1977,382 .

112 Shipbuilding Conference annual reports various years, NMM,TT SRNA.

113 For this, see, NPL reorganisation of Ship Division into a Maritime Institute, 1974, TNA, FV92/7.
} 
symbiotically linked, the fortunes of one were ultimately dependent on the other. Both came relatively late in their development to industry wide research, but both BSRA and PAMETRADA were the first of their kind in the world. Research for practical purposes was from the beginning a medium to long-term strategy, and given that there was more than an element of government cajoling to set up research associations with the aim of improving competitiveness, it was crucial that government through DSIR and successor Departments of State provided monies to aid the process. Had they not done so, the process of atomistic firmcentred research would undoubtedly have continued.

However, research, properly done and financed is by its nature time-consuming and expensive, and there was undoubtedly an element of the shipbuilding industry continuing to pay its contribution, and basically just getting on with building ships in the seller's market of the late 1940s and 1950s regardless of the benefits of continuing research applicable to the industry. This criticism is primarily aimed at the shipbuilders and their marine engine building establishments.

Admiralty criticism of Parsons marine turbines falling behind their American competitors was entirely justified, but that criticism became a self-fulfilling prophesy. It left the door open for YARD in design and consultancy and the land turbine firms AEI and English Electric, and GEC in design and manufacture to dominate the motive power for warships of the Royal Navy.

PAMETRADA began with out of date designs and little organisation. It did not have much to show for all the work it put into gas turbines, the initial design was unworkable, and subsequent designs never got beyond the paper stage. In terms of machinery tests, PAMETRADA's lessons learned in naval turbine testing undoubtedly aided its merchant ship designs. That over 7mshp of Pametrada designed steam turbines provided motive power for merchant vessels is testament that it got some things right. However, it had no control over manufacture of its designs by licencees and standards thereon, or over licensees going their own way, particularly on warship work for the Admiralty and manufacturing to land turbine firms designs. Although by 1962, when the engine builders formed the new Pametrada, it claimed, unconvincingly, to have rectified its problems of control.

The old PAMETRADA also had no control over persistent Admiralty bias towards the land firms, evident since it produced in 1944 the working drawings of five of the Daring class ships built as after that auspicious start no other PAMETRADA designs were accepted by the Admiralty. Steam turbines came to be superseded for reasons of fuel economy by slow and medium speed diesel engines in merchant ships, and by gas turbines in warships. Pametrada with its reliance on steam turbines was caught in a pincer movement. The supremacy of marine main diesel engines, particularly in medium speed, became even more pronounced in the 1970s and 1980s.

In the end the new Pametrada, shorn of much of its membership, and in historic and contemporary terms suffering a distinct lack of finance, and with little room for its designs in changing markets, threw in the towel in 1967. A year later the QE2 debacle tarnished its reputation in the eyes of the public at large, an ignominious 
end to a ground-breaking organisation.

For Doxford and by association Pametrada, the main, and in many cases, virtually the only market for UK steam turbine and slow speed diesel manufacturers was likely to remain the British shipbuilding industry. Its continuance was ultimately dependent on the share of the market engine builders were able to secure linked directly to the success or failure of British shipbuilding firms obtaining orders from British shipowners in sufficient numbers to maintain critical mass in the industry. For Doxford, and the same applied to Pametrada, both had no real control over manufacturing under licence.

Doxford's management in the 1950s were undoubtedly to blame for the firm's later misfortunes in the engine building sector. Too little financial resources were given to $\mathrm{R} \& \mathrm{D}$ and by the time these resources were reluctantly given, the market had moved on and Doxford were left firmly behind. It was not as if Doxford management were privy to imperfect information; the egregious J. Ramsay Gebbie was Chairman of BSRA in 1953 and was surely kept up to date then and later with developments in diesel prime movers. He arrogantly decided that Doxford engines were appropriate for the ships he built at Pallion, giving no real thought to the general increase in ship sizes apparent to anyone reading Lloyd's Register of Shipping's Annual Summaries or the trade press.

Post the SIC report of 1965-66, rationalisation of production facilities for the manufacture of slow speed diesels and marine steam turbines was necessary, and that concentration and specialisation could best be achieved on a regional basis (Clyde, Tyne and Wear) given the particular markets to be served. BSRA, whose chairmen were always shipbuilders, is a more difficult case than Pametrada to assess the value of its research to the shipbuilding industry. Its work on hydrodynamics and cavitation in conjunction with the Ship Division of the NPL was valuable as was its early experiments on resistance and propulsion. How far the benefits of BSRA research up to the early 1960s, as opposed to Pametrada old and new, which were more immediate in that they resulted in proven products, permeated down to the shipbuilding industry is highly debatable. BSRA produced annual reports, but just how many people in shipyard or engineering management actually read them and improved their facilities or processes and products remains unknown.

The establishment of a Production Research Section before the Patton report of 1962 and its work with that report's membership, brought Sir Maurice Denny's then forlorn insistence on the primacy of research on production methods in 1944 to stark recall. Had BSRA concentrated on this ab initio, then the industry might have been in a better place to answer the increasing and then overwhelming threat of international competition.

The merging of BSRA and some sections of Pametrada in 1962 and its change of title and functions, although there was a lag effect here, occurred by which stage it was evident that British shipowners were deserting the industry and ordering abroad. Shipowners had always been represented on the BSRA Council through Chamber of Shipping nominees; however, we now had a distinct change of focus in that we had two industries, shipping and shipbuilding, whose interests 
fundamentally diverged on the demand and supply sides, with one replacing the other.

One could quite rightly pose the question, what really was the point of BSRA to the British shipbuilding industry from 1944 to 1962 ? This in no way denigrates the professionalism and dedication of BSRA staff and the quality of their research. One could stress the point made in the Booz-Allen and Hamilton report of 1972 that by the early 1970 s, research on hydrodynamics, resistance and propulsion had advanced to a stage when diminishing returns in cost savings were likely to occur. Moreover, by 1970, 74 percent of British shipowners were ordering abroad leaving the British shipbuilding industry and BSRA in an ever diminishing market. However, the change of research focus by government in 1974 suited BSRA's then structure, and to a large extent ensured its survival.

We can say with certainty, however, that in considering research organisations in British shipbuilding and main marine engine manufacture, there was no positive correlation between industrial research and industry (shipbuilding and shipping) growth. If anything, the reverse was true. 